\title{
E-Government Asset Management Using the Extreme Programming Method
}

\author{
Taqwa Hariguna ${ }^{\text {a, }}$, Mirra Tsamara ${ }^{\text {a }}$ \\ ${ }^{\text {a } I n f o r m a t i o n ~ S y s t e m ~ P r o g r a m, ~ S T M I K ~ A M I K O M ~ P u r w o k e r t o ~}$ \\ * corresponding author
}

\begin{abstract}
Village Asset Management is a village property derived from the original property of the village, purchased or acquired for the expense of the village's income and expenditure budget (APBDes) or other legitimate acquisition of rights. In this study is the management of the village assets Kebumen Baturraden subdistrict and The problems acquired are the recording of village assets and the realization of the budget of the village assets that are still written so it takes A long time, Therefore the purpose in This research is to help and facilitate management performance in village Asset listing. Methods of collecting data using observations, interviews and Library studies. System development method using the Extreme programming method consisting of four phases of system development, namely planning, design, coding and test. The result of this research is a Village Asset Management E-Government using the Extreme Programming method of the Kebumen Village case study. The conclusion of this research is that it can simplify the management and realization of village assets budget due to the two interconnected reporting are reports of budget realization and village Asset report.
\end{abstract}

Keywords: Village Asset Management, Extreme Programming, E-Government

\section{Introduction}

This increasingly rapid technological development is no doubt. People of various groups have already felt the impact of the development of this technology. But very unfortunate use is often in the wrong use even harm. Not only its own use, but also other people around it. Technology is intended to facilitate human beings. It is useful to use wisely. It can even be utilized by state apparatus or government in managing and utilizing technology to accelerate and facilitate the processing of data. In fulfilling the needs of the increasingly diverse society in the future must be developed systems with modern. Therefore, to realize a government that is increasingly better one effort is to use information and communication technology called e-Government.

According to [1] with the history of the development of e-Government concept there is the trigger is globalization that comes faster than predicted to have made issues such as democracy, law, transparency, corruption of human rights, civil society, good government,free trade, open market, etc. become the main thing that every nation should notice if it does not want to be separated from the world's associations[2][3]. And the advancement of information technology has been rapidly so that data, information and knowledge can be created quickly and can be disseminated throughout the world in a matter of seconds. As for the increasing quality of life of society that increasingly improved the performance of private industry in conducting its economic activities. With the acceleration of performance enhancement of private sector, this is not followed by the same acceleration with the public sectors, so that the public can see the presence of the quality standards in providing service[4][5].

In order to support the planning of quality development in Central Java and effective development control, necessary data management that is accurate, current, integrated, complete, accountable, dynamic, reliable, accessible and sustainable is supported by a thorough, sharp and comprehensive analysis [6][7].

To enforce the provisions of article 113 of government Regulation No. 43 year 2014 on Implementation Regulation No. 6 year 2014 about the Village as amended by Government Regulation number 47 year 2015 about the amendment of the Government Regulation No. 43 year 2014 on Regulation of Implementing Law number 6 year 2014 about Village, need to set regulation of the Minister of Home Affairs on village Asset Management [7][9] 
According to the Ministry of State Regulation No. 1 of 2016 article 19 of the fifth paragraph of security reads to prevent the function of goods, a decrease in the number of goods and the loss of goods need administration, such as bookkeeping, investarisation, Reporting and storage of proprietary documents[8][11].

At the time of research found the problem is still difficulty in recording asset data due to the many assets owned[10]. The delay in filling the asset data is also influential in the village profile and monographic data that should be the information that the community needs to monitor government performance[12].

\section{Research Methods}

\subsection{Data Collection Methods}

a. Interview

b. Observation

c. Documentation

d. Library Studies

\subsection{System Development Methods}

System development methods used in the development of E-Govenment Asset Management The village is Extreme Programming (XP) which is small-scale software and also requires a prolonged development time [13][14].

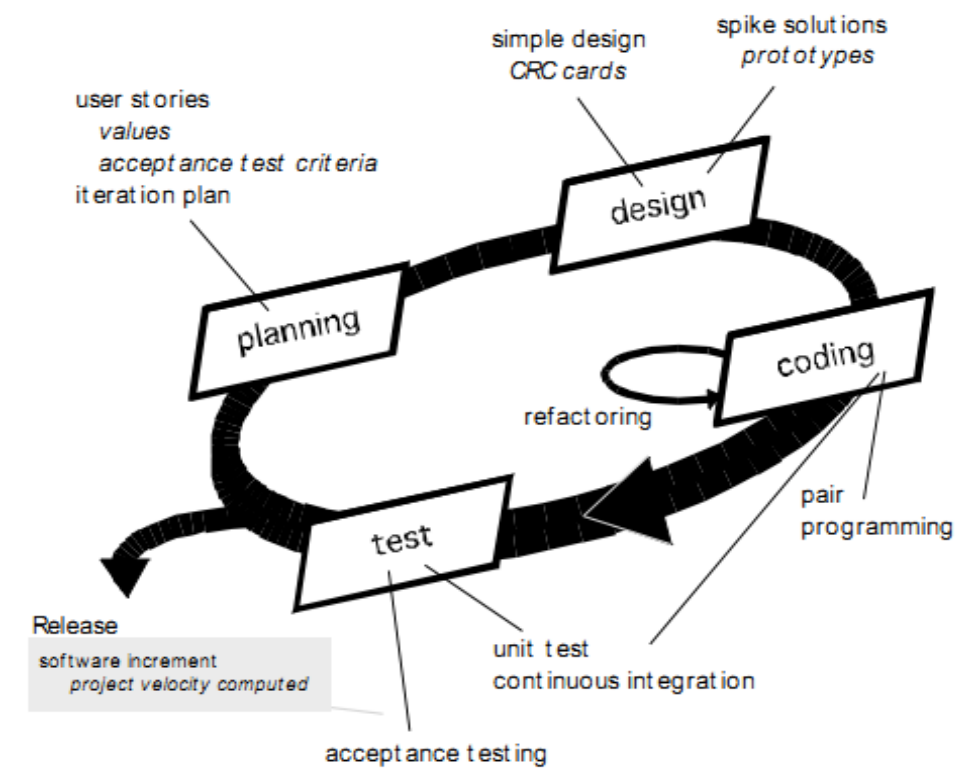

Fig 1. Extreme Programming Scheme

\section{Results and Discussion}

\subsection{Planning}

At this stage the planning of the desired system refers to the user stories. User stories describe the features and functions required of the system. When all user stories are defined, the developer will determine the length of work for each user's stories[15]. Planning can be done when already know the limits of any problem in the e-Government asset Management Village.

Based on the results of identification or analysis of the use needs made by the author, the author can describe the user requirement on the project that the author will develop, among others:

a. Login feature, to access the application by entering an identity with a user account that has been owned.

b. Main Page Features 


\section{1) Supporting Data}

In this menu there is a sub Menu master transaction account that is to classify the realization of transactions and sub-menu employees to save user data/user

2) Accounting Data Settings

In this menu there are 3 (three) Sub menus i.e. sub menu account Group function to group accounting transactions, Sub Menu master Accounting function to specify the financial journals, and Sub Menu setting period function to set the active period and fiscal year.

3) Data on budget realization

In this menu there is a sub menu that is a list of budget realization function to display the result of the realization transaction that has been saved in the Master Sub menu of the transaction account.

\section{4) Reporting}

In this menu there are two sub menus that are sub menu of the asset report and sub menuof the budget Realization report.

c. Welcome feature, in this menu is for administrators to log out of the application.

d. Theme features, that is to set the theme as desired by the user/user.

\subsection{Design}

a. Use Case Diagram

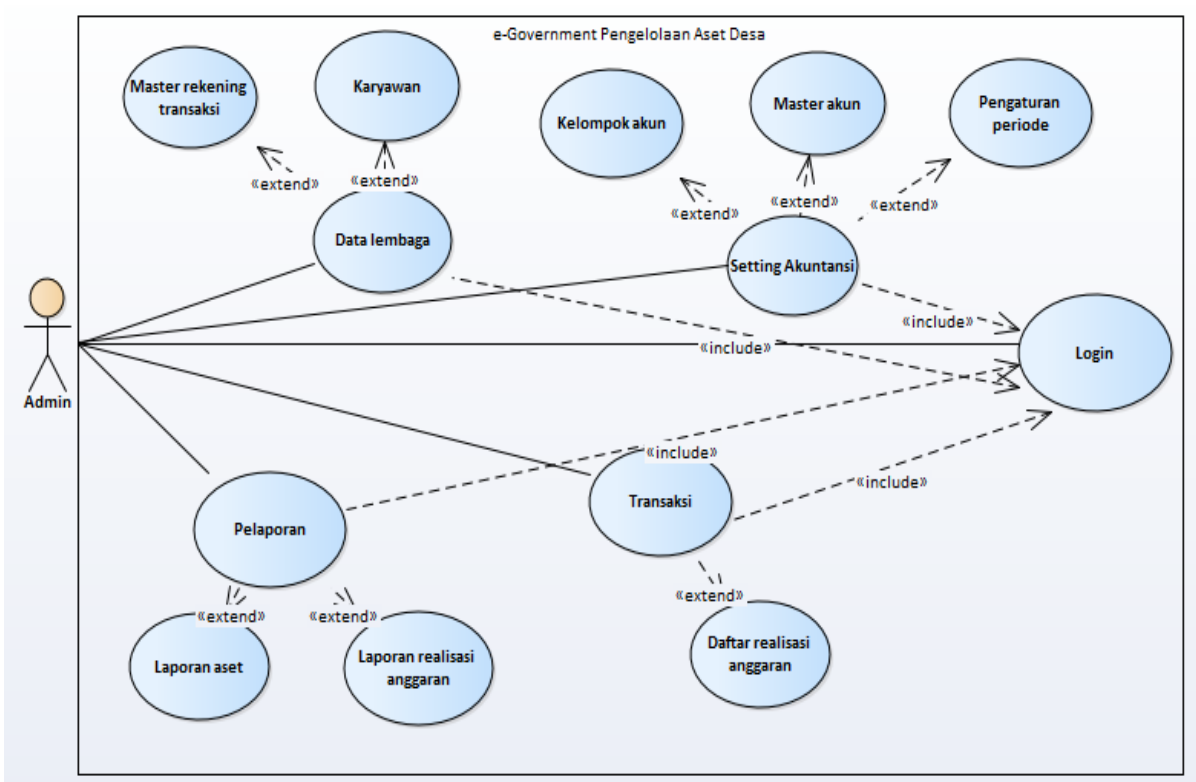

Fig 2. Village Asset Management Use Case Diagram 
b. Class Diagram

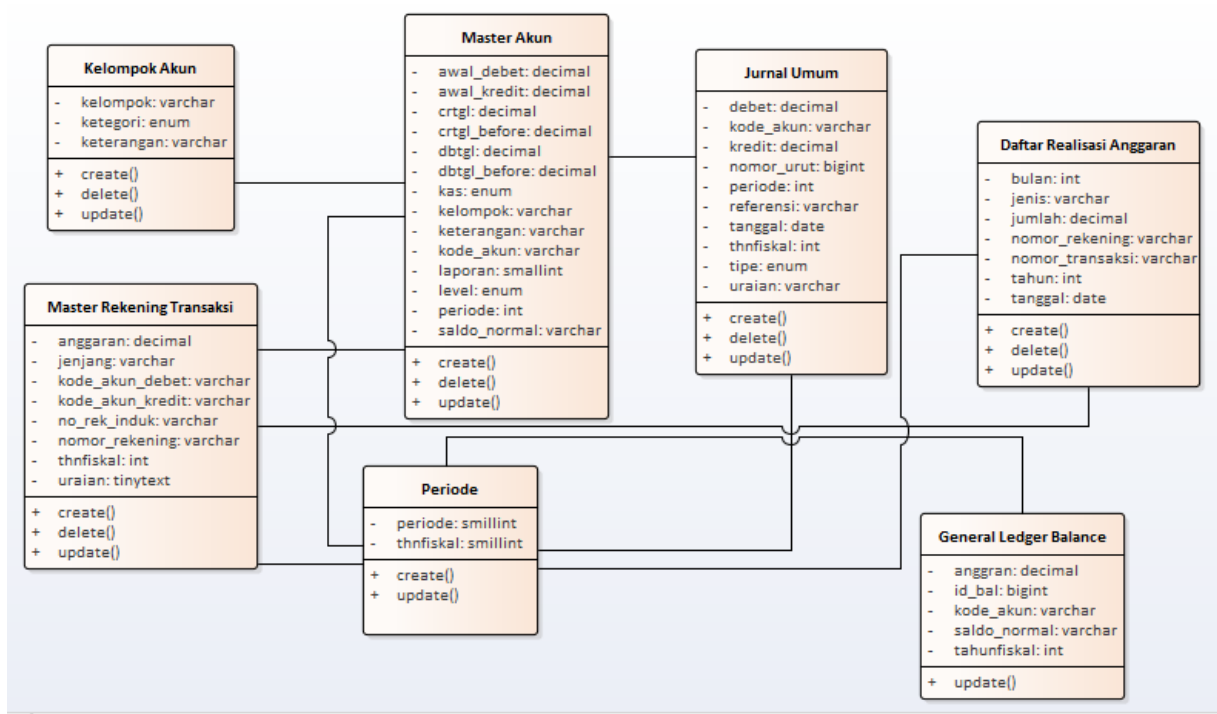

Fig 3. Village Asset Management Class Diagram

\subsection{Coding}

The writer's coding phase uses the CodeIgniter framework.

a. Model Coding

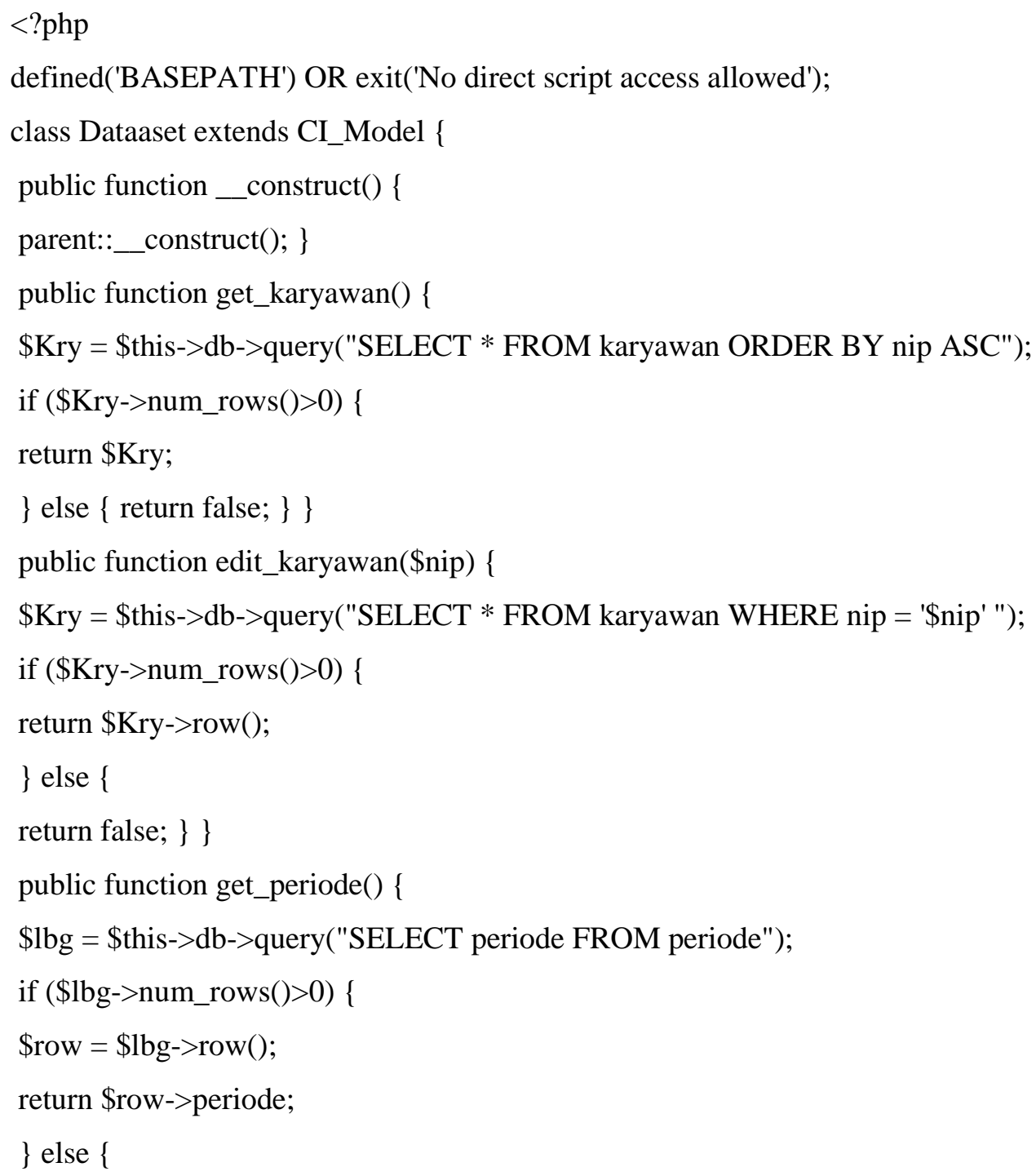


Taqwa Hariguna, Mirra Tsamara / Vo1. 2, No. 1, March 2019, pp. 24-32

return substr(date('Y-m-d'), 5, 2); \} \}

public function get_thnfiskal() \{

$\$ 1 b g=$ this->db->query("SELECT thnfiskal FROM periode");

if $(\$$ lbg->num_rows ()$>0)\{$

\$row $=\$$ lbg->row ()

return \$row->thnfiskal;

\} else \{

return substr(date('Y-m-d'), 0, 4); \} \}

public function get_nomor_master_rekening_baru(\$lvl, \$rek_induk) \{

\$posisi = 2;

if $(\$ \operatorname{lvl}==1)\{$

\$posisi = 2;

b. Controller Coding

$<$ ?php

defined('BASEPATH') OR exit('No direct script access allowed');

class Dashboard extends CI_Controller \{

public function___construct() \{

parent::_construct();

\}

public function login() \{

\$data['title'] = 'Setiap pengguna masuk log terlebih dahulu ';

\$data['status'] = \$this->uri->segment(3);

//View

\$this->load->view('v_login', \$data);

\}

public function login_check ()\{

\$user $=$ \$this->input->post('kode_user', TRUE);

\$pass $=\$$ this- $>$ input-> post('password', TRUE);

$\$$ query $=$ "SELECT $*$ FROM karyawan WHERE kode_user $=$ '\$user' AND password $=$ md5('\$pass')";

$\$$ sql $=\$$ this $->$ db->query $($ query $)$;

if $(\$$ sql->num_rows ()$==0)\{$ 
Taqwa Hariguna, Mirra Tsamara / Vo1. 2, No. 1, March 2019, pp. 24-32

redirect('Dashboard/login/gagal');

\} else \{

\$hsl $=\$$ sql- $>$ row () ;

\$this->session->set_userdata('loggedin', 'true');

\$this->session->set_userdata('nip', \$hsl->nip);

\$this->session->set_userdata('namalengkap', \$hsl->namalengkap);

// echo 'berhasil'; exit;

\$this->index();

\}

\}

public function logout() \{

//

\$this->session->unset_userdata('loggedin');

\$this->session-> unset_userdata('nip');

\$this->session->unset_userdata('namalengkap');

\$this->session->sess_destroy();

//

redirect('Dashboard/login', 'refresh'); \}

c. View Coding

!DOCTYPE html>

$<\mathrm{html}>$

$<$ head $>$

$<$ meta charset="utf-8">

<meta http-equiv="X-UA-Compatible" content="IE=edge">

$<$ title>LOGIN APLIKASI | PENGELOLAAN ASET</title>

$<$ !-- Tell the browser to be responsive to screen width -->

$<$ meta content="width=device-width, initial-scale $=1$, maximum-scale $=1$, user-scalable $=$ no"

name $=$ "viewport">

$<$ !-- Bootstrap 3.3.6 -->

$<$ link rel="stylesheet" href="<?php echo base_url('themes/bootstrap/css') ?>/bootstrap.css">

<!-- Font Awesome -->

$<$ link rel="stylesheet" href="<?php echo base_url('themes/font-awesome/css') ?>/font-

awesome.min.css">

$<$ !-- DataTables -->

$<$ link rel="stylesheet" href="<?php echo base_url('themes/plugins/datatables')

?>/dataTables.bootstrap.css">

$<!--$ Ionicons --> 
Taqwa Hariguna, Mirra Tsamara / Vo1. 2, No. 1, March 2019, pp. 24-32

$<$ link rel="stylesheet" href="<?php echo base_url('themes/ionicons/css') ?>/ionicons.min.css"> $<!--$ Theme style -->

<link rel="stylesheet" href="<?php echo base_url('themes/dist/css') ?>/AdminLTE.css">

$<$ !-- AdminLTE Skins. Choose a skin from the css/skins

folder instead of downloading all of them to reduce the load. -->

<link rel="stylesheet" href="<?php echo base_url('themes/dist/css/skins') ?>/_all-skins.min.css"> $<$ !-- HTML5 Shim and Respond.js IE8 support of HTML5 elements and media queries --> <!-WARNING: Respond.js doesn't work if you view the page via file:// --> <!--[if lt IE 9]><script src="https://oss.maxcdn.com/html5shiv/3.7.3/html5shiv.min.js" $\rangle\langle/$ script $\rangle\langle$ script src="https://oss.maxcdn.com/respond/1.4.2/respond.min.js" $\rangle\langle/$ script $\rangle\langle$ ![endif]-- $>$

\subsection{Testing}

\section{a. Unit Test}

Testing These systems created by the authors using the black-box testing testing method is on functions, operations, the program's outer view, and data and information delivery. Following :

Table 1. Unit Test

\begin{tabular}{|l|l|l|}
\hline \multicolumn{1}{|c|}{ Input Data } & \multicolumn{1}{c|}{ Expected results } & \multicolumn{1}{c|}{ Conclusion } \\
\hline $\begin{array}{l}\text { Input username } \\
\text { and password }\end{array}$ & $\begin{array}{l}\text { Can enter the system and can choose } \\
\text { any menu and sub menu that is in the } \\
\text { main menu }\end{array}$ & Success \\
& & \\
\end{tabular}

\section{b. User Acceptance Test (UAT)}

This test uses the results of the testing unit given to the users of the system of governance and general in the Kebumen village. And the results obtained is already in accordance with the needs and procedures that have been established in the state Government Regulation No. 1 year 2016. 


\subsection{App Releases}

\section{Main Page and Menu}

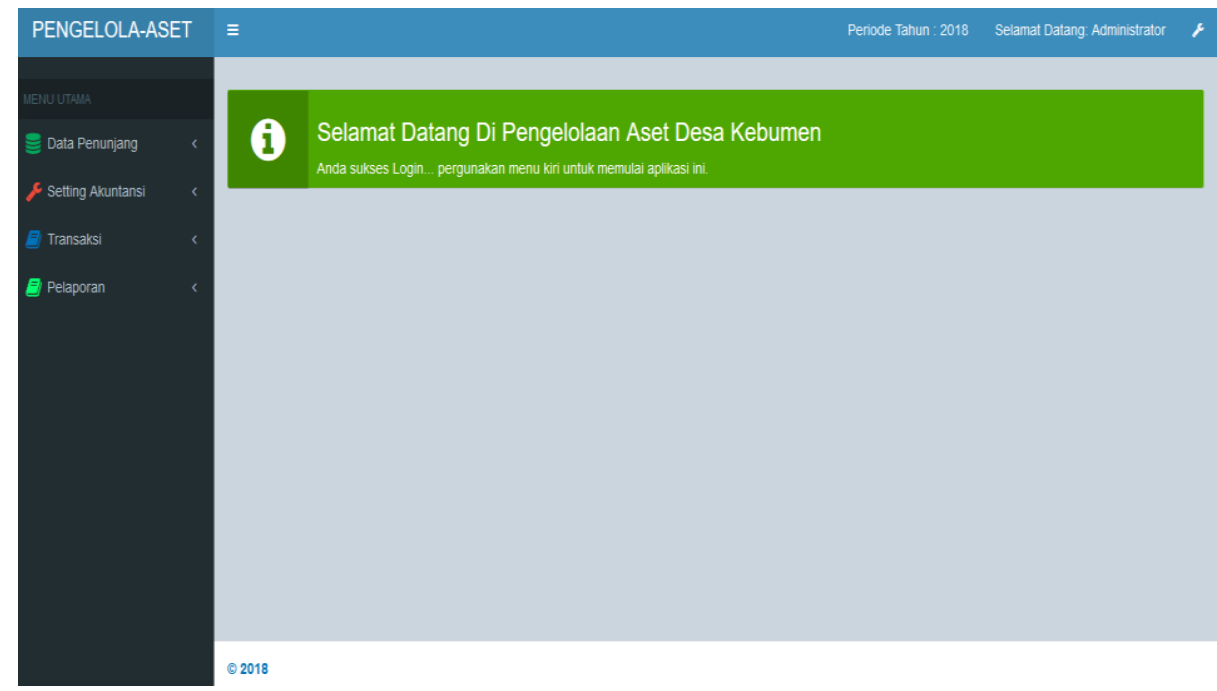

Fig 4. Main Page and Menu Interface

\section{Conclusions and Suggestions}

\subsection{Conclusions}

From the report writing this thesis can be learned several conclusions as follows:

a. It has been created by e-Government of village Asset Management which simplifies the village asset process and the realization of village asset budget using system which is very helpful because there are two interconnected reporting namely Village asset Bounce Report and budget realization report.

b. By using the stage method Extreme Programming in the development of the system that can facilitate the application of communication between developers and clients who have not fully understand the needs of users who want.

c. Based on the final stage testing in the method above the process of filling the data done successfully and functionally the system can produce the expected output after making changes to the system iteration. In terms of user users who use this system is an administrative and General Kaur.

\subsection{Suggestions}

The author's suggestion can be given to researchers who will conduct research on the same topic with the Extreme Programmingmethod. It can provide clarity of time constraints to the needs of the system that is desired by the client and to minimize system changes.

\section{References}

[1] Peraturan Gubernur Jawa Tengah Nomor 52 Tahun 2016 Tentang "Single Data System Untuk Pembangunan Daerah Di Jawa Tengah".

[2] Peraturan Mentri Dalam Negeri Republik Indonesia Nomor 1 Tahun 2016 Tentang "Pengelolaan Aset Desa".

[3] R.S.Pressman, "Software Engineering : a Pracitioner's Approach". New York : Mc-Graw-Hill, 2010.

[4] Alan R. Dennis et al, 2002, "The Object Oriented Team Lessons for Virtual Teams from Global Software Development"[online].source. Available from: http://ieeexplore.ieee.org/iel5/

[5] Alan Serrano,2002," A Study of the Impact of Information Technology on Business Processes Using Discrete Event Simulation", I. J. of Simulation Vol. 2 No. 2, PP 30-40

[6] Badr Haque, Mike James-moore,2009 ," Applying lean thinking to new product introduction”, Journal of Engineering Design, pp 1-31 
Taqwa Hariguna, Mirra Tsamara / Vo1. 2, No. 1, March 2019, pp. 24-32

[7] Balakisnan, S. \& Kanaparan G. ,2006, "Resolving Gathering of User Requirements- A Lightweiht Methodology Approach in the Development Maturity Level Websites”, Asia Pacific University College of Technology and Innovation, Technology Park Malaysia

[8] Balthazar et al,2004, "Shared Leadership And Group Interaction Styles In Problem Solving Virtual Teams," Proceedings of the 37th Hawaii International Conference on System Sciences, Hawaii, pp. 1-10.

[9] Bing Yang et al, 2009, "Experimental Analysis of Logical Progress Simulation Algorithms in James II", Proceedings of the 2009 Winter Simulation Conference, pp 1167-1179

[10] Christopher Thomson et al, 2008, “Applying XP Ideas Formally. The Stroy Card and Extreme X-Machines” [online]. Source, Available From: http://delab.csd.auth.gr/bci1/SEEFM03/seefm03_05.pdf

[11] Daniel Johnson, Peter Sutton\&Neil Harris,2001, “eXtreme Programming Require Extremely Effective Communication Teaching Effective Communication Skills to Student in an IT Degree”, pp 81-84

[12] Daniel S.Wall, James McHale, Marsha Pomeroy-Huff, 2007, “Case Study, Accelerating Process Improvement by Integrating TSP and CMMI”, Software Engineering Institute, Carengie Mellon

[13] David J. Paper, James A. Rodger, Parag C. Pendharkar, 2001,“BPR Case Honeywell”, BPM Journal Vol 7No 2, pp 85-99

[14] Deepti Mishra, Alok Mishra, 2009, "Effective Communication, Collaboration and Coordination in eXtreme Programming Human Centric Prespective in a Small Organization “, Human Factors and Ergonomics in Manufaturing Vol 19,pp 438-356,

[15] Diane Elizabeth Strode, 2005, "The Agile Methods An Analytical Comparison of Five Agile Methods and an Investigation of their Target Environment", Thesis (Master), Massey University of New Zeland. 